\title{
Mixing and switching of speech codes of Ukrainian emigration (on the example of memoirs and epistolary works by Ulas Samchuk)
}

\section{Змішування та перемикання мовленнєвих кодів української еміграції (на прикладі мемуарних та епістолярних творів Уласа Самчука)}

Mariia Panhelova

Ph.D. in Philology
Марія Пангелова

кандидат філологічних наук

\footnotetext{
E-mail: pangelova1985@gmail.com orcid.org/0000-0002-2240-7122

Researcher I: P-2636-2018
}

\author{
Pereiaslav-Khmelnytskyi \\ Hryhorii Skovoroda State \\ Pedagogical University \\ 30, Sukhomlynskyi Str., \\ Pereiaslav-Khmelnytskyi, \\ Ukraine, 08401
}

ДВНЗ «Переяслав-Хмельнищький держсавний педагогічний університет імені Григорія

Сковороди»

$\triangle$ вул.Сухомлинського 30 , м. Переяслав-Хмельницький, Україна, 08401

Original manuscript received February 15, 2018

Revised manuscript accepted October 20, 2018

\begin{abstract}
The problem of switching and mixing codes is extremely relevant in foreign and domestic linguistic science over the past decades. In this case, if codeswitching is understood by all researchers more or less equally (switching from one language to another within a single text - dialog or monologue), then by mixing the code (code-mixing), the case looks much more complicated. The term "mixing of codes» is understood by different researchers in fundamentally different ways: from the introduction into one language of the elements of another language in almost unlimited quantities and in the unadapted
\end{abstract}


Mixing and switching of speech codes of Ukrainian emigration...

(phonetically and grammatically) form before switching codes within the same sentence, that is, the kind of switching codes (the second approach thus postulates the process of speaking in two languages and removes the fundamental difference between switching codes and mixing codes).

The study of the mixing of speech codes is an interesting and promising branch of research on the theory of language contacts. Among the fundamental works on this subject should be the study of P. Muysken (Muysken, 2000), where he provides a detailed typology of situations of mixing language codes. In linguistic research, there is a widespread practice of using "mixing codes" and "switching codes» as interchangeable, as well as a series of studies where the term "mixing codes" is used to describe and switch codes and massive borrowings. While the term "switching codes" emphasizes the transition of bilingual from one grammatical system to another, the term "mixing codes» implies the presence of hybrid forms associated with both grammars. In other words, mixing codes emphasizes the formal aspects of linguistic structures or linguistic competence, while code switching emphasizes linguistic performance.

The psycho-linguistic direction concerning the study of the switching of speech codes among the bilingual environment explains which aspects of the linguistic competence of bilinguals allow them to modify the codes. Often, the choice of a foreign language involves a waiver of the synonymous form in the language of the successor of the language, thus opposed to an alternative way of expressing communicative intentions in a foreign language.

The purpose of our scientific studio is to present function the mixing and switching codes on the materials of the memoirs ("Planet DP») and the epistolary works of Ukrainian writers-emigrants in Canada, in particular, by Ulas O. Samchuk with his colleagues, publishers, etc. The main methods of research used were: the method of comparative analysis, which allows to detect English-language infusions as units of English, which determine the national-cultural specificity of the English language; the method of component analysis, which allowed to reveal the semantic interrelations of British realities; descriptive method and method of content analysis. In the course of the study, we came to the conclusion that the addressee and addressees, real masters of the artistic word, almost do not allow the English language to be spoken in Ukrainian, or such spraying is deliberately used and is a means of language play.

Key words: switching language code, mixing speech codes, language contact, epistol, memoir.

\section{Вступ}

Предметом вивчення психолінгвістики $є$ «співвідношення особистості зі структурою та функціями мовленнєвої діяльності 
та мовою як головною «твірною» образу світу людини», «розгляд особливостей роботи механізмів породження та сприйняття мовлення» (Леонтьев, 1997: 18-19).

Перехід мовознавчої науки від структурно-функціональної парадигми до когнітивної розширив межі дослідження одиниць мови за рахунок включення національно-культурних асоціацій, властивих цим одиницям у процесі їх функціонування у певному лінгвокультурному середовищі, що уможливило переклад національно-маркованої лексики 3 урахуванням досягнень лінгвокультурології. Активізація процесів міжкультурного спілкування та виявлення у мовах різних народів специфічних національно-маркованих компонентів сприяли розгляду мови як феномена культури, а лексичних одиниць - як засобу відображення національно-культурної інформації. В умовах сьогодення національно-культурна специфіка мови досліджується у межах різних галузей мовознавства: когнітології (Попова, 2007; Evans, 2007; Норр \& Schmid, 2013), лінгвокультурології (Алефіренко, 2010; Bochner, 2013; Metge, 2013; Suvorova \& Polyakova, 2018), лінгвокраїнознавства (Гапонів, 2005) та психолінгвістики (Ахутина, 1985; Леонтьев, 2005; Швець, 2017: 201).

Проблема перемикання кодів $\epsilon$ надзвичайно актуальною та широко обговорюваною в зарубіжній та вітчизняній психолінгвістиці впродовж останніх десятиріч. Процеси мовного контактування, що наявні в епістолярних та мемуарних текстах письменника української еміграції Уласа Самчука на регулярній основі, ще не були предметом спеціального вивчення. Отже, нерозв'язаність означеної проблеми у сучасній лінгвістичній науці зумовила актуальність означеного дослідження.

Метою нашої статті $є$ представлення функціонування змішування та перемикання кодів у мовленні українських письменників-емігрантів на матеріалах мемуарних творів та приватних кореспонденцій.

\section{Методи дослідження}

У статті для вивчення функціонування змішування та перемикання кодів на матеріалах мемуарних («Плянета Ді-Пі») та епістолярних творів українських письменників-емігрантів у Канаді, зокрема Уласа Олексійовича Самчука з його колегами по 
Mixing and switching of speech codes of Ukrainian emigration...

перу, видавцями використано як основні метод спостереження, порівняльного аналізу, описовий метод та метод контентаналізу. На різних етапах дослідження послуговувалися методом функціонального аналізу для визначення стилістичного навантаження лексичних одиниць.

Для дослідження матеріалу в статті використовується метод контент-аналізу 3 метою формування стислого та загального викладу досліджуваного явища. Метод контент-аналізу передбачав розбивку матеріалу на смислові блоки, транскрипцію матеріалу, класифікацію, узагальнення тощо.

Контент-аналіз листів У. Самчука (всього було проаналізовано епістоли до 5 різних адресатів періоду 1950-1965 рр.) засвідчив той факт, що учасники листування, високоосвічені та культурні люди, які майже не допускають у мовленні українською мовою англійських вкраплень, або такі вкраплення використовуються навмисне та слугують засобом мовної гри. Водночас, на підставі здійсненого контент-аналізу можемо зробити висновки про те, що чисельні вкраплення англійською мовою не можуть бути зрозумілими українськими читачами, які не володіють англійською мовою, а роль вкраплень у книзі мемуарів «Плянета Ді-Пі» очевидно велика, можна припустити, що ймовірною аудиторією У. Самчука є українські емігранти Америки, Канади та Німеччини, скоріше ніж його співвітчизники, що лишилися в Україні.

\section{Результати та дискусії}

Явища перемикання та змішування кодів являють собою надзвичайне зацікавлення для сучасних вчених. Означеній проблематиці була присвячена праця Є. Проценко «Проблема перемикання кодів у зарубіжній лінгвістиці» (Проценко, 2004), де було подано огляд поглядів та підходів зарубіжних дослідників щодо вивчення означеної проблеми. Перемикання мовних кодів визначається як почергове використання елементів двох або більше мов у рамках одного комунікативного акту більш або менш двомовним мовцем (Проценко, 2004: 123). Є. Проценко зазначає, що першим у цій сфері став У. Вайнрах. Слідом за У. Вайнрахом виділяються три основні комплекси факторів перемикання кодів або три напрями дослідження: зовнішні, екстралінгвістичні «оn the spot» або соціолінгвістичні; внутрішні, психолінгвістичні та, 
нарешті, власне лінгвістичні серед яких найчастіше розглядаються граматичні, синтаксичні або структурні питання. Зарубіжні дослідники дійшли висновку про те, що скласти вичерпний перелік соціальних сфер перемикання кодів (the domains for codeswitching) $\epsilon$ практично неможливим. Дослідниками неодноразово підкреслювалось, що кодове перемикання може може виконувати функцію етнічної ідентифікації (Myers-Scotton, 1997: 217-237). У своїй розвідці $Є$. Проценко враховує зарубіжних вчених, котрі займалися означеною проблематикою (Bhatt, 1997; Becker, 1999; Jacobson, 1990; Auer, 1990; Eppler, 1994; Finlayson, 1997; Goldstein, 1999; Hanse, 2000 та ін.).

Узагальнюючи сучасні зарубіжні дослідження, Є. Проценко (2004) зазначає, що, не дивлячись на чисельні дослідження стосовно проблеми перемикання кодів, до нині лишається низка невирішених питань. Одним із них $є$ проблема диференціації термінів перемикання кодів та запозичень.

Деякі дослідники пропонують запровадити додаткові терміни, такі як змішування мов - «codemixing» (Milroy, 2004; Sridhar, 1998) або «вставне» перемикання - «insertional codeswitching» (Sankoff, 1998).

При цьому, якщо перемикання кодів (code-switching) розуміється усіма дослідниками більш або менш однаково (перехід 3 однієї мови на іншу в межах одного тексту - діалогічного або монологічного), то зі змішуванням кодів (code-mixing) справа виглядає значно складніше. Сам термін «змішування кодів» розуміється різними дослідниками принципово по-різному: від уведення до мовлення однієї мови елементів іншої мови у майже необмеженому обсязі та в неадаптованому (фонетично та граматично) вигляді до перемикання кодів у межах одного речення, тобто, різновиду перемикання кодів (при другому підході тим самим постулюється процес говоріння на двох мовах і знімається принципова різниця між перемиканням кодів i змішуванням кодів) (Русан, 2016: 58).

Також С. Проценко розглядає сфери перемикання кодів. На думку автора, перемикання кодів може бути застосоване у будь-якій сфері (вдома, на роботі, в засобах масової інформації тощо). Проте, його поява зумовлена рядом чинників, найважливішими 
Mixing and switching of speech codes of Ukrainian emigration...

3 яких є учасники комунікації, ситуація та умови комунікації (Проценко, 2004: 123).

Опираючись на соціолінгвістичні дослідження, автор доходить висновку про те, що саме характеристики учасників грають головну партію під час вибору того чи іншого мовного коду. «С. СільваКорвалан дійшла висновку про те, що незалежно від оточуючих умов мовець не буде перемикати мовні коди в тому випадку, якщо це може призвести до збою комунікації або якщо йому не відомі лінгвістична компетенція та мовні вподобання інших учасників комунікації» (Проценко, 2004: 123-124).

О. Жиганова підкреслює, що явище кодового перемикання являє собою «мотивований процес, так як воно виконує певну функцію в ситуації спілкування. Змішування кодів є спонтанним, та часто відбувається всередині тісно пов'язаного словосполучення та функціонально не є мотивованим» (Жиганова, 2011: 34).

Проте, межі між змішуванням i перемиканням кодів чітко не встановлені, та більшість дослідників цієї сфери не поділяють ці поняття.

Ми ж будемо розуміти під змішуванням кодів використання в мовленні неадаптованих лексичних елементів іншої мови i, тим самим, допускати можливість принципового розрізнення випадків перемикання кодів та змішування кодів.

Г. Пилипенко доходить до висновку, що перемикання кодів відбувається при більш значному переносі, що перевищує стандарти звичайної інтерференції, при цьому висловлювання чітко сигналізують про приналежність до означеної мови (Пилипенко, 2010: 72).

О. Русаков зазначає, що проблематика, пов’язана зі змішуванням та перемиканням кодів, посідає означене місце в літературі, присвяченій мовним контактам. Вчений уточнює, що перш за все ці явища розглядаються 3 соціолінгвістичної та прагматичної точок зору, зокрема, вивчаються конкретні фактори, що впливають на появу перемикання кодів: тема бесіди, реалії, що згадуються в тексті, звернення до одного або різних співрозмовників, моменти, пов’язані з внутрішньою будовою тексту (Русаков, 1998).

Питанню перемикання кодів також присвячена студія О. Зеленіна «Тато, де моя lipka?». У праці досліджуються причини 
перемикання кодів, такі як відсутність відповідного еквіваленту в словниковому складі іншої мови, забування слова в процесі мовоутворення, частотність (фреквентативність) того чи іншого слова в будь-якій мові, структурні особливості мов, соціальні, психологічні обставини. Як зазначає О. Зеленін, 3 точки зору передачі актуальної інформації та повсякденної комунікації досить часто необхідним та достатнім критерієм під час діалогу виявляється вкраплення іншомовного слова чи поняття (якщо передбачається, що співрозмовники знають його, знайомі з ним), ніж звернення до словника в пошуках відповідного еквіваленту (Зеленин, 2008: 472).

У статті О. Зеленін розрізнюе змішування кодів на фонологічному, морфологічному, лексичному, синтаксичному та семантичному рівнях.

Як зазначає автор роботи, тип змішування кодів на фонологічному рівні досліджений не достатньо, дослідження цієї сфери стосуються переносу (трансферу) фонем з однісї мови в іншу. Їй присвячені праці М. Мюрреля (Murrel, 1966), Е. Оксаара (Oksaar, 1991), М. Шнітцера (Schnitzer, 1996), Е. Красинського (Krasinski, 1996), М. Парадіса (Paradis, 2001). Прийнято вважати, що вплив однієї мови на іншу на фонологічному рівні менш значущий, ніж на інших рівнях, але водночас, автор вважає, що фонологія може бути однією із можливих причин змішування кодів. Наприклад, у ситуаціях, в яких лексеми іншої мови являють для мовця відому складність $з$ точки зору артикуляції, вимови, йому легше вжити лексему 3 іншої мови 3 менш проблемним (3 позиції мовця) фонологічним складом (Зеленин, 2008: 473).

Морфологічне та лексичне змішування мов $\epsilon$, на думку О. Зеленіна, найбільш дослідженим. Цьому типу змішування кодів були присвячені праці (Murrel, 1966; Burling, 1959; Lindholm, 1978; Padilla, 1978; Redlinger, 1980; Park, 1980; Meisel, 2001; Lanza, 2001 та ін.). При морфологічному змішуванні кодів відбувається поєднання (контамінація) морфем із різних мов у одному гібриді.

О. Зеленін вважає, що найбільш частотним типом синтаксичного змішування кодів є змішування порядку слів у різних мовах. Лінгвіст зазначає, що змішування іменників та дієслів у побудові фрази відображає взаємодію лексичного та синтаксичного ярусів у лінгвосвідомості мовця (Зеленин, 2008: 473-474). 
Mixing and switching of speech codes of Ukrainian emigration...

Семантичне змішування кодів проявляється в тому, що білінгв використовує слово у невідповідній, невластивій означеній мові ситуації, але цілком прийнятній в іншій мові.

Досліджуючи лінгвістичні матеріали на означену тему, можна дійти до висновку, що проблема змішування та перемикання кодів все більше приваблює зарубіжних та вітчизняних вчених.

Дослідниця Т. Ахутіна вважає, що при змішуванні кодів обидва лінгвістичні коди беруть участь лише в «словесному представленні» (при доборі слів), водночас як «механізм граматичного структурування» задіє лише один код (Ахутина, 1985: 98). Під час перемикання коду обидва коди активізовані як на рівні, що актуалізує поле номінації, так і в «схемі часового розгортання, що актуалізує поле предикації» (Ахутина, 1985: 94).

П. Майскен і Р. Аппель, аналізуючи соціальні, психологічні та лінгвістичні аспекти мовного контакту на прикладі іспанської мови і мови кечуа в Андах, зміну мови між пропозиціями або фразами називають «alternational» codeswitching - чергується перемикання коду, а включення слова або фрази всередині пропозиції називають «insertional» codeswitching - інсерційно перемикання кодів (лат. inserto - вставляти, вкладати) (Аppel \& Muysken, 2005: 119). С. Томасон називає зміну коду, яка відбувається всередині пропозиції (intrasentential - інтрасентенціальний перехід) - перемикання коду, а між пропозиціями (intersentential - інтерсентенціальний перехід) (Thomason, 2001: 132). Результати дослідження перемикання кодів С. Томасон на прикладі американських білінгвів, які володіють ідиш і англійською мовою, мають загальнотеоретичний характер i цілком можна застосувати до нашої ситуації.

До вивчення епістолярію українського письменника канадського екзилю Уласа Олексійовича Самчука майже ніхто не звертався, лише такі вчені як В. Кузьменко (1999) та Г. Мазоха (2006) поверхово окреслили шляхи його подальшого вивчення.

У статті 3. Бичко «Діалектизми як важлива риса мови художніх творів Уласа Самчука» доходить висновку, що всі ці діалектизми органічно, гармонійно поєднуються із живим народним мовленням, $\epsilon$ тими компонентами, за допомогою яких автор надає текстові розмовного забарвлення, наближує твір до народу, розкриває світосприймання, індивідуалізує сам роман. Учений зауважує, що письменник володіє південно-західним варіантом української мови, 
елементи якого зберігаються донині в системі мови української художньої літератури. Використання діалектизмів пояснюється не лише стилістичними настановами автора, але й тим, що вони $є$ рівноправними елементами мовної організації художнього тексту (Бичко, 2000).

У досліджуваному нами приватному листуванні та книзі мемуарних спогадів «Плянета Ді-Пі» українського письменникаемігранта У. Самчука присутня велика кількість прикладів перемикання та змішування кодів. При цьому автор використовує як традиційну орфографію, так і транскрипцію, що відображає вимову цих слів.

Епістолярна спадщина У. Самчука складається 3 декількох пластів: один відображає життя письменника, як емігранта та майстра художнього слова в еміграції 3 усіма складнощами перебування в Канаді, звідки його думки линуть до спогадів, якими він живе. Інший являє собою спомини письменника про життя у Німеччині та інших країнах Європи під час Другої світової війни (книга спогадів «Плянета Ді-Пі»). Окрім двох основних сюжетних ліній увазі адресантів (читачів) пропонуються ліричні відступи, що дозволяють нам отримати панорамний огляд життя та минулого автора, та окреслюють нам життя його колег по перу на Батьківщині та різних континентах. Перед нами постає ціла галерея найрізноманітніших людських портретів, особливо тих, які представляють нам майже всі творчі хвилі української еміграції в Канаді.

I досить логічним $\epsilon$ те, що на явища змішування та перемикання кодів ми натрапляємо у листах, що відносяться до канадського періоду листування автора, що відображає тогочасні реалії, водночас, у листах, що описують життя німецького періоду, ми скоріше натрапляємо на німецькі вкраплення. У мовленні адресата, цього періоду відсутні англійські вкраплення.

Як зазначає проф. М. Котова у монографії, присвяченій ідентичності слов'янських письменників, «тотальна домінанта англійських вкраплень у мовленнєвих характеристиках слов'янських емігрантів у англомовному оточенні Канади як показник гібридної мовної ідентичності героїв» $\epsilon$ стилетворчою рисою ідентифікації слов'янського емігранта (Котова, 2014: 112). 
Mixing and switching of speech codes of Ukrainian emigration...

Варто зауважити, що мовлення у деяких листах до таких адресатів як, М. Борецького, О. Веретенченка, I. Вовчука, Є. Маланюка, родини Погайдаків, переданий текст англійською мовою відповідно до української орфографії. Автор користується означеним прийомом невипадково, тим самим вказуючи на ступінь володіння мовою того чи іншого емігранта. Наприклад, у листі до М. Борецького від 29.05.1950 року читаємо: «Я шукав для Вас «ашураншиста», але на таку велику родину просто не можна було нічого зробити» (ВРФТІЛНАН України Ф. 195. Оп. 357. Арк. 3). Або ж у листі до О. Веретенченка від 22.09.1959 року натрапляємо на таке: «Ми були два тижні на фармі, їздили по воду» (ВРФТІЛНАН України Ф. 195. Оп. 381 Арк. 1). У листах до I. Вовчука нам зустрічаються наступні вкраплення англійської мови: «Засадничо / моя особиста опінія / твір буде цікавий» (ВРФТІЛНАН України Ф. 195. Оп. 391. Арк. 4 від 04.03.1958 р.).; «Не писав, бо сам викінчую «Чого не гоїть вогонь», щоб скорше Вам вислати скрипт» (ВРФТІЛНАН України Ф. 195. Оп. 391. Арк. 5 від 24.10 .1958 р.); «Щось сталося, що забули вислати мені обіцяну pamy z 100.00» (ВРФТІЛНАН України Ф. 195. Оп. 391. Арк. 6 від 16.01 .1959 р.). У листах до Є. Маланюка ми також маємо змогу побачити наступні англомовні вкраплення: «Ми несемо консеквениії за наші вірування, наші ідеали, наші погляди» (ВРФТІЛНАН України Ф. 195. Оп. 639. Арк. 5 від 31.12.1963 р.); «I чи маєте сатисфакцію, що я буду також замітати? Ви були поетом на $100 \%$, я є прозаїком на 100\%...» (ВРФТІЛНАН України Ф. 195. Оп. 639. Арк. 7 від 23.05.1965р.). Наведені вище приклади демонструють метод порівняльного аналізу, який полягає у виявленні англомовних вкраплень як одиниць англійської мови, що детермінують національно-культурну специфіку англійської мови.

Очевидним видається той факт, що культура, текст (художній) людини мовця співіснують у єдиному комунікативному просторі; текст утворюється людиною як мовленнєво-розумовий продукт та являється одиницею комунікації, за допомогою якої відбувається діалог між автором та читачем як представниками означених (можливо, різних) історичних періодів, культур та / або субкультур тощо. Текст (особливо художній) - це вмістилище культури, відображення ментального простору людини та дійсності 
(матеріальної та духовної), закріпленої в символах мови та за допомогою символів мови висловлювання (Янь Кай, 2016: 301).

Л. Крисін зазначає, що однією із особливостей мовленнєвої поведінки інтелігентних носіїв мови - це вміння перемикатися в процесі комунікації з одних різновидів мови на інші в залежності від умов спілкування. Ця поліглосність відрізняє інтелігенцію, наприклад, від носіїв просторіч, які є моноглосними та не вміють варіювати своє мовлення в залежності від ситуації (Крысин, 2001).

Поліглосність забезпечується механізмом кодових перемикань, який виробляється у людини в процесі їі соціалізації до культурного мовленнєвого середовища. Засвоєння системи соціальних ролей, які властиві означеному суспільству, йде у нерозривному зв'язку iз засвоєнням норм мовленнєвої поведінки, що забезпечують оптимальне виконання тієї чи іншої ролі. А варіювання цих норм значною мірою є можливим лише тому, що мова надає мовцеві різноманітних засобів вираження однакових комунікативних інтенцій, i відповідних сенсів. Різноманітні засоби мовного вираження виявляються немов би притягнутими до різноманітних умов спілкування, до різних комунікативних ситуацій, до виконання тих чи інших соціальних ролей (Крысин, 2001).

Таким чином, можемо стверджувати про те, що освічені адресати здатні переключатися з однієї мови на іншу, без змішування мови, водночас, говорячи про менш інтелігентних представників української еміграції, ми маємо справу зі змішуванням кодів.

Наприклад, у книзі мемуарів «Плянета Ді-Пі» У. Самчук демонструє своє бачення стосовно об’єднання українських мистецьких сил за кордоном, активно листується. Свою позицію щодо ідеї створення «МУРу» У. Самчук занотував у вищеназваній книзі спогадів від 5 грудня 1945 р.: «Цікава, культурна, талановита людина (мовиться про І. Костецького. - М.П.) і цього хай вистачає. I прибув він з місією заангажувати мене до організації, яку вони там - Фюрт-Мюнхен-Ульм, вже створили, назвали МУР, що значить Мистецький Український Рух, а оце, через Костецького, хочуть нагородити мене титулом ii голови. O, mein Gott!!! (Самчук, 1979: 20). Далі маємо змогу читати наступне: «Чи дасть це, питаєте, відповідь? Рішення? Не відповіді і не рішення, а свідомість. Бо ж то свідомість - завдаток пізнання. Und fragst du noch warum dein Herz; Sich bang in deinem Busen klemmt; Warum ein unerklarter Schmerz; 
Mixing and switching of speech codes of Ukrainian emigration...

Dir alle Lebensregung hemt? Пригадується щось 3 «Фавста» (Самчук, 1979: 19). Або пропонуємо такий ілюстративний німецькомовний матеріал: «Увага! Увага! Америка плекає нову серію Троцьких i Бабелів. Це їх головами і їх капіталами готовиться нова навала на свободу «вільноrо світа». Ettention! Hannibal anti porte!» (Самчук, 1979: 70); «Робили також екскурсію в гори і оглянули славетний, казковий замок - фантазію дивовижноro короля Баварії Людвика II - Schloss Neuschwanstein» (Самчук, 1979: 88); «Прочитав також роман «Der Schuldtrager» Меєра. Не маю доброї белетристики» (Самчук, 1979: 107).

Проблема змішування кодів повною мірою була представлена у творчості іншого митця української діаспори в Канаді - Івана Багряного, $з$ яким У. Самчук вів тривале листування, і якому в одному зі своїх листів наголошував цього не робити. У листі У. Самчука до I. Багряного датованим 30.01 .1950 року читаємо: «I ще одно. Оце недавно дзвонив до мене Василь Левицький i просив мене передати Вам привіти, як також просив, щоб Ви не вживали у Ваших гуморесках англо-українського жаргону. Я до його думки також цілком приєднуюсь. Не можемо вводити такої «моди» навіть, коли це стосується гумору. Англо-україн. жаргон один 3 найвульгарніших i зовсім нам не притаманний. 3 того можуть пізніше виникнути поважні мовні ускладнення, а головне, шкода Вас, як автора, бо повірте мені - це не здобуде Вам права на літературу. Ви лише змарнуєте Ваші здібності. Пишіть, працюйте... < ..> Навіть не треба йти слідами Стефаника, що до місцевого діялекту. Тут треба йти за взірцями О. Генрі, Чехова, а найкраще Марка Твейна. Різні діялекти і жаргони зовсім зникають у перекладі і що тоді лишається? <...> А знаючи мову англійську, тут для нашого брата невичерпальні скарби знання... Англійська література - найкраща у світі» (до Багряного). У. Самчук дає зрозуміти своєму колезі по перу, якими можуть бути наслідки взаємодії двох мов.

\section{Висновки}

Засоби передачі іншомовних вкраплень в мемуарних та епістолярних творах У. Самчука вказують нам на рівень освіченості та рівень володіння англійською та німецькою мовою дописувачами. Так, повні вкраплення, передані відповідно до 
англійської традиції написання, характеризують вільне володіння англійською мовою учасників листування. Водночас вкраплення, що фонетично або морфологічно адаптовані українською мовою, вказують на недостатне володіння англійською мовою учасника листування. Учасники листування, високоосвічені та культурні, майже не допускають у мовленні українською мовою англійських вкраплень, або такі вкраплення використовуються навмисне та слугують засобом мовної гри. Отже, можемо зробити висновки про те, що чисельні вкраплення англійською мовою не можуть бути зрозумілими українськими читачами, які не володіють англійською мовою, а роль вкраплень у книзі мемуарів «Плянета Ді-Пі» очевидно велика, можна припустити, що ймовірною аудиторією У. Самчука є українські емігранти Америки, Канади та Німеччини, скоріше ніж його співвітчизники, що лишилися в Україні.

\section{Література}

Алефиренко, Н.Ф. Лингвокультурология: ценностно-смысловое п пространство языка. Москва : Флинта : Наука, 2010. 288 с.

Ахутина, Т.В. Исследование речевого мышления в психолингвистике. Москва : Наука, 1985. 240 с.

Бичко, 3. Діалектизм як важлива риса мови художніх творів Уласа Самчука. Наукові записки. Серія: Літературознавство. 2000. Вип. 6. С. 121-124.

Гапонів, А.Б., Возна М.О. Лінгвокраїнознавство. Англомовні країни / за заг. ред. В.В. Бондаренко. Вінниця : Нова Книга, 2005. 464 с.

Жиганова, А.В. Роль переключения языкового кода в рекламе. Вестник Нижегородского государственного лингвистического университета им. Н.А. Добролюбова. 2011. Вып. 13. С. 33-41.

Зеленин, А. «Папа, где моя lipka?» (доминантный язык и смешение кодов в русско-финском онтобилингвизме). Slavica Halsingiensia. С любовью к слову. 2008. № 35. C. 469-482.

Котова, М.Ю. Сегменты идентичности в творчестве зарубежных славянских писателей. Санкт-Петербург : Изд-во С.-Петерб. ун-та, 2014. 142 с.

Крысин, Л.П. Современный русский интеллигент: попытка речевого портрета. Русский язык в научном освещении. 2001. Вып. 1. С. 90-106.

Леонтьев, А.А. Основы психолингвистики. Москва : Смысл; Академия, 2005. $288 \mathrm{c}$.

Кузьменко, B.I. Письменницький епістолярій в українському літературному процесі 20-50-х років XX ст. : автореф. дис. ... д-ра філол. наук : 10.01.01. Київ : КНУ ім. Т. Шевченко, 1999. 34 с.

Мазоха, Г.С. Український письменницький епістолярій другої половини XX століття: жанрово-стильові модифікації. Київ : Міленіум, 2006. 344 с.

Пилипенко, Г.П. Разработка вопросов интерференции и заимствования в лингвистической литературе. Славяноведение. 2010. Вып. 1. С. 62-73. 
Mixing and switching of speech codes of Ukrainian emigration...

Попова, 3.Д., Стернин, И.А. Когнитивная лингвистика Москва : АСТ : ВостокЗапад, 2007. 314 с.

Проценко, Е.А. Проблема переключения кодов в зарубежной лингвистике. Вестник ВГУ. Серия «Лингвистика и межкультурная коммуникация». 2004. Вип. 1. С. 123-127.

Русаков, А.Ю. Северно-русский диалект цыганского языка: интерференция и переключение кодов. Этнолингвистические исследования. Взаимодействие языков и диалектов. 1998. Вып. 21. 162-191.

Русан, А.В. Смешение и переключение кодов речи чешских эмигрантов. Международный научно-исследовательский журнал. 2016. Вып. 6(48). Часть 4. С. 56-60.

Самчук, У. Плянета Ді-Пі: Нотатки й листи. Вінніпег : Накладом Т-ва «Волинь», 1979. $356 \mathrm{c}$.

Швець, Т.А. Національно-маркована лексика французької мови - способи перекладу українською мовою : тези доповідей XII Міжнародної науковопрактичної конферениії «Психолінгвістика в сучасному світі» (26-27 жсовтня 2017 року). Переяслав-Хмельницький : ФОП «Домбровськая Я.М.», 2017. C. 201-203.

Янь, Кай. Художественный текст, культура, сознание: психолингвокультурологический поход. Bопросы психолингвистки. 2016. Вып. 4(30). C. 298-310.

Appel, R., \& Muysken, P. (2005). Language Contact and Bilingualism. Amsterdam : Amsterdam University Press. DOI: 10.2307/327522

Auer, P. (1998). Code-switching in conversation: language, interaction and identity. London : Routledge.

Becker, K. (1999). Spanish/English bilingual codeswitching: a syncretic model. Bilingual review, 22(1), 3-31.

Bhatt, R.M. (1997). Codeswitching, constraints, and optimal grammars. Lingua, 102, 223-251. https://doi.org/10.1016/S0024-3841(97)00007-7

Bochner, S. (2013). Cultures in Contacts: studies in cross-cultural interaction. New York : Pergamon Press.

Burling, R. (1959). Language development of a Garo and English speaking child. Word, 15, 45-68. DOI:10.1080/00437956.1959.11659683

Eppler, E. (1994). Code-switching in «Emigranto». Vienna English working papers, 3. $75-94$.

Evans, V. (2007). A Glossary of Cognitive Linguistics. Edinburgh : Edinburgh University Press. https://www.textosenlinea.com.ar/libros/Evans\%20-\%20A\%20 Glossary\%20of\%20Cognitive\%20Linguistics\%20-\%202007.pdf

Finlayson, R. (1997). «I'll meet you halfway with language»-codeswitching functions within an urban context. South African journal of linguistics, 15(4), 123-135. https://doi.org/10.1080/10118063.1997.9724121

Goldstein, T. (1999). One speaker, two language: book review. Canadian Modern Language Review, 55(4), 560-566.

Hansen, M.-B. (2000). The syntactic and semiotic status of direct quotes with reference to French. Transactions of the Philological Society, 98(2), 281-323. https://doi. org/10.1111/1467-968X.00066

Hopp, H., \& Schmid, M. (2013). Perceived foreign accent in first language attrition and second language acquisition: The impact of age of acquisition and 
Змішування та перемикання мовленнєвих кодів української еміграції...

bilingualism. Applied psycholinguistics, 34, 361-394. http://dx.doi.org/10.1017/ S0142716411000737

Jacobson, R. (1990). Codeswitching as a worldwide phenomenon. New York : Peter Lang.

Lanza, E. (2001). Bilingual first language acquisition: A discourse perspective on language contact in parent-child interaction. In J. Cenoz \& F. Genesee (Eds.), Trends in bilingual acquisition (pp. 201-230). Amsterdam : John Benjamins.

Lindholm, K. (1978). Language mixing in bilingual children. Journal of Child Language, 5, 327-335. https://doi.org/10.1017/S0305000900007509

Meisel, J.M. (2001). The simultaneous acquisition of two first languages: Early differentiation and subsequent development of grammars. In J. Cenoz \& F. Genesee (Eds.), Trends in language acquisition research, Vol. 1. Trends in bilingual acquisition (pp. 11-41). Amsterdam : John Benjamins. http://dx.doi. org/10.1075/tilar.1.03mei

Metge, J. (2014). Talking past each other: Problems of cross-cultural communication. New Zealand : Victoria University Press. https://trove.nla.gov.au/work/9641654

Milroy, L., \& Muysken P. (1995) One speaker, two language; cross-disciplinary perspectives on cross-switching. Cambridge : Cambridge University Press. https:// doi.org/10.1017/CBO9780511620867

Murrel, M. (1966). Language acquisition in a trilingual environment: Notes from a case study. Studia Linguistica, 20, 9-35. https://doi.org/10.1111/j.1467-9582.1966. tb00531.X

Muysken, P. (2000). Bilingual Speech: A Typology of Code-mixing. Cambridge : Cambridge University Press. http:/catdir.loc.gov/catdir/samples/ cam032/99056423.pdf

Myers-Scotton, C. (1997). Code-Switching. In F. Coulmas (Ed.), The Handbook of Sociolinguistics (pp. 217-237). Oxford : Blackwell.

Oksaar, E. (1991). Problematik im interkulturellen Verstehen. Interkulturelle Wirtschaftskommunikation. München : Judicium.

Paradis, J. (2001). Do bilingual two-year olds have separate phonological systems? International Journal of Bilingualism, 5, 19-38. https://doi.org/10.1177/1367006 9010050010201

Patton, M. (2002). Qualitative Research \& Evaluation Methods. 3rd ed. Thousand Oaks, CA : Sage. 453.

Redlinger, W.E., \& Park, T.Z. (1980). Language mixing in young bilinguals. Journal of Child Language, 7, 337-352. https://doi.org/10.1017/S030500090000266X

Sankoff, D. (1998). The production of code-mixed discourse. Proceedings of COLINGACL '98: 36 ${ }^{\text {th }}$ Annual Meeting of the Association for Computational Linguistics and 17th International Conference on Computational Linguistics. (pp. 8-21). Montreal, (Vol. 1.).

Schnitzer, M.L., \& Krasinski, E. (1996a). The development of segmental phonological production in a bilingual child: A contrasting second case. Journal of Child Language, 23, 547-571. https://doi.org/10.1017/S0305000900008941

Schnitzer, M.L. (1996b). Knowledge and acquisition of the Spanish verbal paradise in five communities. Hispania, 79, 830-844.

Sridhar, S.N., \& Sridhar, K.K. (1980). The syntax and psycholinguistics of bilingual code mixing. Canadian Journal of Psychology. Revue canadienne de psychologie, 34 (4), 407-416. 
Mixing and switching of speech codes of Ukrainian emigration...

Suvorova, E., \& Polyakova, L. (2018). Double inference in the processes of comprehension of russian and english discourse complicated by an idiom. The Southeast Asian Journal of English Language Studies, 24(2), 43-57. http://doi. org/10.17576/3L-2018-2402-04

Thomason, S.G. (2001). Language Contact. Edinburgh : Edinburgh University Press. http://www-personal.umich.edu/ thomason/temp/lgcont1.pdf

\section{Джерела}

Лист Уласа Самчука до І. Багряного від 30.01.1950 р.// (Відділ рукописних фондів і текстології Інституту літератури ім. Т.Г. Шевченка НАН України) Ф. 195, № 320. Арк. 1.

Лист Уласа Самчука до М. Борецького від 29.05.1950 p.// (Відділ рукописних фондів і текстології Інституту літератури ім. Т.Г. Шевченка НАН України) Ф. 195, № 357. Арк. 3.

Лист Уласа Самчука до О. Веретенченка від 22.09.1959 р. // (Відділ рукописних фондів і текстології Інституту літератури ім. Т.Г. Шевченка НАН України) Ф. 195, № 381. Арк. 1.

Листи Уласа Самчука до І. Вовчука від 04.03.1958 p.; 24.10 .1958 р.; 16.01.1959 р. // (Відділ рукописних фондів і текстології Інституту літератури ім. Т.Г. Шевченка НАН України) Ф. 195, № 391. Арк. 4, 5, 6.

Листи Уласа Самчука до Є. Маланюка від 31.12 .1963 р.; 23.05.1965 р. // (Відділ рукописних фондів і текстології Інституту літератури ім. Т.Г. Шевченка НАН України) Ф. 195, № 639. Арк. 5, 7.

\section{References}

Alefirenko, N.F. (2010) Lingvokulturologiia: tsennostno-smyslovoe prostranstvo yazyka [Lingvo Cultural Studies: the value-semantic space of the language]. Moscow : Flinta: Nauka [in Russian].

Ahutina, T.V. (1985) Issledovanie rechevogo myshleniya $v$ psiholingvistike [The study of speech thinking in psycholinguistics]. Moscow : Nauka [in Russian].

Bychko, Z. (2000). Dialektyzm yak vazhlyva rysa movy khudozhnikh tvoriv Ulasa Samchuka [Dialecticism as an important feature of the language of the works of Ulas Samchuk]. Naukovi zapysky. Seriia: Literaturoznavstvo - Scientific notes. Series: literary Studies, 6, 121-124 [in Ukrainian].

Haponiv, A.B., Vozna, M.O. \& Bondarenko, V.V. (2005). Linghvokrainoznavstvo. Anghlomovni krainy [Linguistic Studies. English-speaking countries]. Vinnytsia : Nova Knyha [in Ukrainian].

Zhiganova, A.V. (2011). Rol perekliuchenija yazykovogo koda $\mathrm{v}$ reklame [The role of code switching in advertisement]. Vestnik Nizhegorodskogo hosudarstvennogo lingvisticheskogo universiteta im. N.A. Dobroljubova - Bulletin of the Nizhniy Novgorod N.A. Dobrolubov State Linguistic University, 13, 33-41 [in Russian].

Zelenin, A. (2008). «Papa, gde moja lipka?» (dominantnyi yazyk i smeshenie kodov V russko-finskom ontobilingvizme) [«Daddy, where is my lipka?» (Dominant language and code mixing in Russian-Finnish ontotalism)]. Slavica Halsingiensia. $S$ ljubovju $k$ slovu - Slavica Halsingiensia. With love for the word, 35, 469-482 [in Russian].

Kotova, M.Ju. (2014). Segmenty identichnosti v tvorchestve zarubezhnyh slavianskih pisatelei [Segments of identity in the work of foreign Slavic writers]. St. Petersburg : Izd-vo S.-Peterb. un-ta [in Russian]. 
Змішування та перемикання мовленнєвих кодів украӥнської еміграції..

Krysin, L.P. (2001) Sovremennyj russkij intelligent: popytka rechevogo portreta [The modern Russian intellectual: attempt of a verbal portrait]. Russkij jazyk $v$ nauchnom osveshhenii - Russian language in scientific light, 1, 90-106 [in Russian].

Leontiev, A.A. (2005) Osnovy psiholingvistiki [Fundamentals of psycholinguistics]. Moscow : Smysl, Akademija [in Russian].

Kuzmenko, V.I. (1999). Pysmennytskiy epistoliarii v ukrainskomu literaturnomu protsesi 20-50-kh rokiv XX st. [Writing epistolary in the Ukrainian literary process of the 20-50s of the twentieth century]. Extended abstract of Doctor's thesis. Kyiv : KyivNU [in Ukrainian].

Mazokha, H.S. (2006). Ukrainsjkiy pysmennytskiy epistoliariy druhoi polovyny XX stolittia: zhanrovo-styliovi modyfikatsii [Ukrainian Writing Epistolium of the Second Half of the 20th Century: Genre-Style Modifications]. Kyiv : Milenium [in Ukrainian].

Pilipenko, H.P. (2010). Razrabotka voprosov interferentsii i zaimstvovaniia v lingvisticheskoy literature [Development of questions of interference and borrowing in the linguistic literature]. Slavianovedenie - Slavic Studies, 1, 62-73 [in Russian].

Popova, Z.D., \& Sternin, A. Kognitivnaya lingvistika [Cognitive linguistics]. Moscow : AST : Vostok-Zapad [in Russian].

Protsenko, E.A. (2004). Problema perekliucheniia kodov v zarubezhnoy lingvistike [The problem of switching codes in foreign linguistics]. Vestnik VGU, Seriia "Lingvistika $i$ mezhkulturnaia kommunikatsiia» - Bulletin of Voronezh State University, Series «Linguistics and Intercultural Communication», 1, 123-127 [in Russian].

Rusakov, A.Yu. (1998). Severno-russkiy dialekt tsyganskogo yazyka: interferentsiia i perekliuchenie kodov [North-Russian dialect of the Gypsy language: interference and code switching]. Etnolingvisticheskiie issledovaniia. Vzaimodeystvie iazykov $i$ dialektov - Ethnolinguistic research. Interaction of languages and dialects, 21, 162-191 [in Russian].

Rusan, A.V. (2016). Smesheniie i perekliuchenie kodov rechi cheshskih emigrantov [Mixing and switching of speech codes of Czech immigrants]. Mezhdunarodniy nauchno-issledovatelskii zhurnal - International Research Journal, 6(48). Vol. 4, 56-60 [in Russian].

Samchuk, U. (1979). Plianeta Di-Pi: Notatky i lysty [The Planet Dipi: Notes and Letters]. Winnipeg : Nakladom T-va «Volyn» [in Ukrainian].

Shvets, T.A. (2017). Natsionalno-markovana leksyka frantsuzkoi movy - sposoby perekladu ukrainskoiu movoiu [The national-language vocabulary of the French language is a way of translating into Ukrainian]. Proceedings from ISPC'17: XII Mizhnarodna naukovo-praktychna konferentsiia «Psykholinhvistyka $v$ suchasnomu sviti» - The twelfth International Scientific and Practical Conference «Psycholinguistics in modern world» (pp. 201-203). Pereiaslav-Khmelnytsky : IE «Dombrovska Ya.M.» [in Ukrainian].

Yan, Kay. (2016). Khudozhestvennyi tekst, kultura, soznaniie: psikholingvokulturolohicheskiy podhod [Art text, culture, consciousness: psycho linguistic and cultural approach]. Voprosy psikholongvistiki - Journal of psycholinguistics, 4(30), 298-310 [in Russian].

Appel, R., \& Muysken, P. (2005). Language Contact and Bilingualism. Amsterdam : Amsterdam University Press. DOI: 10.2307/327522 
Mixing and switching of speech codes of Ukrainian emigration...

Auer, P. (1998). Code-switching in conversation: language, interaction and identity. London : Routledge.

Becker, K. (1999). Spanish/English bilingual codeswitching: a syncretic model. Bilingual review, 22(1), 3-31.

Bhatt, R.M. (1997). Codeswitching, constraints, and optimal grammars. Lingua, 102, 223-251. https://doi.org/10.1016/S0024-3841(97)00007-7

Bochner, S. (2013). Cultures in Contacts: studies in cross-cultural interaction. New York : Pergamon Press.

Burling, R. (1959). Language development of a Garo and English speaking child. Word, 15, 45-68. DOI:10.1080/00437956.1959.11659683

Eppler, E. (1994). Code-switching in «Emigranto». Vienna English working papers, 3. $75-94$.

Evans, V. (2007). A Glossary of Cognitive Linguistics. Edinburgh : Edinburgh University Press. https://www.textosenlinea.com.ar/libros/Evans\%20-\%20A\%20 Glossary\%20of\%20Cognitive\%20Linguistics\%20-\%202007.pdf

Finlayson, R. (1997). «I'll meet you halfway with language» - codeswitching functions within an urban context. South African journal of linguistics, 15(4), 123-135. https://doi.org/10.1080/10118063.1997.9724121

Goldstein, T. (1999). One speaker, two language: book review. Canadian Modern Language Review, 55(4), 560-566.

Hansen, M.-B. (2000). The syntactic and semiotic status of direct quotes with reference to French. Transactions of the Philological Society, 98(2), 281- 323. https://doi. org/10.1111/1467-968X.00066

Hopp, H., \& Schmid, M. (2013). Perceived foreign accent in first language attrition and second language acquisition: The impact of age of acquisition and bilingualism. Applied psycholinguistics, 34, 361-394. http://dx.doi.org/10.1017/ S0142716411000737

Jacobson, R. (1990). Codeswitching as a worldwide phenomenon. New York : Peter Lang.

Lanza, E. (2001). Bilingual first language acquisition: A discourse perspective on language contact in parent-child interaction. In J. Cenoz \& F. Genesee (Eds.), Trends in bilingual acquisition (pp.201-230). Amsterdam : John Benjamins.

Lindholm, K. (1978). Language mixing in bilingual children. Journal of Child Language, 5, 327-335. https://doi.org/10.1017/S0305000900007509

Meisel, J.M. (2001). The simultaneous acquisition of two first languages: Early differentiation and subsequent development of grammars. In J. Cenoz \& F. Genesee (Eds.), Trends in language acquisition research, Vol. 1. Trends in bilingual acquisition (pp. 11-41). Amsterdam : John Benjamins. http://dx.doi. org/10.1075/tilar.1.03mei

Metge, J. (2014). Talking past each other: Problems of cross-cultural communication. New Zealand : Victoria University Press. https://trove.nla.gov.au/work/9641654

Milroy, L., \& Muysken P. (1995) One speaker, two language; cross-disciplinary perspectives on cross-switching. Cambridge : Cambridge University Press. https:// doi.org/10.1017/CBO9780511620867

Murrel, M. (1966). Language acquisition in a trilingual environment: Notes from a case study. Studia Linguistica, 20, 9-35. https://doi.org/10.1111/j.1467-9582.1966. tb00531.x

Muysken, P. (2000). Bilingual Speech: A Typology of Code-mixing. Cambridge : Cambridge University Press. http://catdir.loc.gov/catdir/samples/ cam032/99056423.pdf 
Змішування та перемикання мовленнєвих кодів украӥнської еміграції..

Myers-Scotton, C. (1997). Code-Switching. In F. Coulmas (Ed.), The Handbook of Sociolinguistics (pp. 217-237). Oxford : Blackwell.

Oksaar, E. (1991). Problematik im interkulturellen Verstehen. Interkulturelle Wirtschaftskommunikation. München : Judicium.

Paradis, J. (2001). Do bilingual two-year olds have separate phonological systems? International Journal of Bilingualism, 5, 19-38. https://doi.org/10.1177/1367006 9010050010201

Patton, M. (2002). Qualitative Research \& Evaluation Methods. 3rd ed. Thousand Oaks, CA : Sage. 453.

Redlinger, W.E., \& Park, T.Z. (1980). Language mixing in young bilinguals. Journal of Child Language, 7, 337-352. https://doi.org/10.1017/S030500090000266X

Sankoff, D. (1998). The production of code-mixed discourse. Proceedings of COLINGACL '98: $36^{\text {th }}$ Annual Meeting of the Association for Computational Linguistics and 17th International Conference on Computational Linguistics. (pp. 8-21). Montreal, (Vol. 1.).

Schnitzer, M.L., \& Krasinski, E. (1996a). The development of segmental phonological production in a bilingual child: A contrasting second case. Journal of Child Language, 23, 547-571. https://doi.org/10.1017/S0305000900008941

Schnitzer, M.L. (1996b). Knowledge and acquisition of the Spanish verbal paradise in five communities. Hispania, 79, 830-844.

Sridhar, S.N., \& Sridhar, K.K. (1980). The syntax and psycholinguistics of bilingual code mixing. Canadian Journal of Psychology. Revue canadienne de psychologie, 34 (4), 407-416.

Suvorova, E., \& Polyakova, L. (2018). Double inference in the processes of comprehension of russian and english discourse complicated by an idiom. The Southeast Asian Journal of English Language Studies, 24(2), 43-57. http://doi. org/10.17576/3L-2018-2402-04

Thomason, S.G. (2001). Language Contact. Edinburgh : Edinburgh University Press. http://www-personal.umich.edu/ thomason/temp/lgcont1.pdf

\section{Sources}

Lyst Ulasa Samchuka do I. Bahrianoho [Letter from Ulas Samchuk to Ivan Bahrianyi]. (1950, January 30). Viddil rukopysnykh fondiv i tekstolohii Instytutu literatury im. T.H. Shevchenka NAN Ukrainy - Department of Handwriting Funds and Textology of the Institute of Literature named after. T. Shevchenko National Academy of Sciences of Ukraine in Kyiv. f. 195, desc. 320. no. 1

Lyst Ulasa Samchuka do M. Boretskoho [Letter from Ulas Samchuk to Myhailo Boretsky]. (1950, May 29). Viddil rukopysnykh fondiv i tekstolohii Instytutu literatury im. T.H. Shevchenka NAN Ukrainy - Department of Handwriting Funds and Textology of the Institute of Literature named after. T. Shevchenko National Academy of Sciences of Ukraine in Kyiv. f. 195, desc. 357. no. 3.

Lyst Ulasa Samchuka do O. Veretenchenka [Letter from Ulas Samchuk to Oleksa Veretenchenko]. (1959, September 22). Viddil rukopysnykh fondiv i tekstolohii Instytutu literatury im. T.H. Shevchenka NAN Ukrainy - Department of Handwriting Funds and Textology of the Institute of Literature named after. T. Shevchenko National Academy of Sciences of Ukraine in Kyiv. f. 195, desc. 381. no. 1.

Lysty Ulasa Samchuka do I. Vovchuka [Letters from Ulas Samchuk to Ivan Vovchuk]. (1958, March 4; 1959, October 24; 1959, January 16). Viddil rukopysnykh fondiv 
Mixing and switching of speech codes of Ukrainian emigration...

i tekstolohii Instytutu literatury im. T.H. Shevchenka NAN Ukrainy - Department of Handwriting Funds and Textology of the Institute of Literature named after. T. Shevchenko National Academy of Sciences of Ukraine in Kyiv. f. 195, desc. 391. no. 4, 5, 6 .

Lysty Ulasa Samchuka do Ye. Malaniuka [Letters from Ulas Samchuk to Yevhen Malanuik]. (1963, December 31; 1965, May 23). // Viddil rukopysnykh fondiv $i$ tekstolohii Instytutu literatury im. T.H. Shevchenka NAN Ukrainy - Department of Handwriting Funds and Textology of the Institute of Literature named after. T. Shevchenko National Academy of Sciences of Ukraine in Kyiv. f. 195, desc. 639. no. 5,7 .

\section{АНОТАЦІЯ}

Проблема перемикання та змішування кодів $\epsilon$ надзвичайно актуальною в зарубіжній та вітчизняній лінгвістичній науці впродовж останніх десятиріч. При цьому, якщо перемикання кодів (code-switching) розуміється усіма дослідниками більш або менш однаково (перехід з однієі мови на іншу в межах одного тексту - діалогічного або монологічного), то зі змішуванням кодів (code-mixing) справа виглядає значно складніше. Сам термін "змішування кодів» розуміється різними дослідниками принципово по-різному: від уведення до мовлення однієї мови елементів іншої мови у майже необмеженому обсязі та в неадаптованому (фонетично та граматично) вигляді до перемикання кодів у межах одного речення, тобто, різновиду перемикання кодів (при другому підході тим самим постулюється процес говоріння на двох мовах і знімається принципова різниця між перемиканням кодів $i$ змішуванням кодів).

Дослідження змішування мовних кодів - цікава і перспективна галузь досліджень із теорії мовних контактів. Серед фундаментальних праць із цього приводу варто назвати дослідження П. Майскена (Muysken, 2000), де він подає детальну типологію ситуацій змішування мовних кодів. У лінгвістичних дослідженнях існує поширена практика використовувати терміни «змішування кодів» $і$ «перемикання кодів» як взаємозамінні, а також є низка досліджень, де термін «змішування кодів» використовується для опису і перемикання кодів, i масових запозичень. Тоді як термін «перемикання кодів» підкреслює перехід білінгва від однієї граматичної системи до іншої, термін «змішування кодів» передбачає наявність гібридних форм, що пов'язані з обома граматиками. Іншими словами, змішування кодів підкреслює формальні аспекти мовних структур або лінгвістичної компетенції, тоді як перемикання кодів підкреслює мовну активність (linguistic performance).

Психолінгвістичне спрямування щодо вивчення перемикання мовленнєвих кодів серед білінгвального середовища пояснює які аспекти мовної компетенції білінгвів дозволяють їм змінювати 
коди. Найчастіше вибір іншомовної форми передбачає відмову від наявної в системі мови наступника синонімічної форми, тим самим їй протиставляється альтернативний спосіб вираження комунікативних інтенцій іноземною мовою.

Мета нашої наукової студії полягає у представленні функціонування змішування та перемикання кодів на матеріалах мемуарних («Плянета Ді-Пі») та епістолярних творів українських письменників-емігрантів у Канаді, зокрема Уласа Олексійовича Самчука з його колегами по перу, видавиями тощо. В якості основних методів дослідження були використані: метод порівняльного аналізу, що дозволяє виявити англомовні вкраплення як одиниці англійської мови, що детермінують національно-культурну специфіку англійської мови, дескриптивний метод та метод контент-аналізу тощо.

Об'єктом дослідження є мовленнєві коди української еміграції (мемуарні та епістолярні твори Уласа Самчука).

Предмет аналізу - особливості змішування та перемикання мовленнєвих кодів української еміграції Канади (зокрема мемуарні та епістолярні твори Уласа Самчука).

В ході дослідження ми дійшли висновків, що адресат та адресанти, справжні майстри художнього слова, майже не допускають в мовленні українською мовою англійських вкраплень, або ж такі вкраплення використовуються навмисно та являються засобом мовної гри.

Ключові слова: перемикання мовного коду, змішування мовленнєвих кодів, мовний контакт, епістола, мемуаристика.

Пангелова Мария. Смешение и переключение речевых кодов украинской эмиграции (на примере мемуарних и эпистолярных текстов Уласа Самчука)

\section{АННОТАЦИЯ}

Проблема переключения и смешения кодов является чрезвычайно актуальной в зарубежной и отечественной лингвистической науке на протяжении последних десятилетий. При этом, если переключения кодов (code-switching) понимается всеми исследователями более или менее одинаково (переход с одного языка на другой в пределах одного текста - диалогического или монологического), то со смешиванием кодов (code-mixing) дело обстоит значительно сложнее. Сам термин "смешивания кодов" понимается разными исследователями принципиально по-разному: от введения в речь одного языка элементов другого языка почти в неограниченном объеме и в неадаптированном (фонетически и грамматически) виде к переключению кодов в пределах одного предложения, то есть, разновидности переключения кодов (при 
Mixing and switching of speech codes of Ukrainian emigration...

втором подходе тем самым постулируется процесс говорения на двух языках и снимается принципиальная разница между переключением кодов и смешиванием кодов).

Исследование смешивания языковых кодов - интересная и перспективная область исследования теории языковых контактов. Среди фундаментальных трудов в этой области поводу следует назвать исследования П. Майскена (Muysken, 2000), где он подает подробную типологию ситуаций смешивания языковых кодов. В лингвистических исследованиях существует распространенная практика использовать термины "смешивания кодов" и «переключение кодов» как взаимозаменяемые, а также ряд исследований, где термин "смешивания кодов" используется для описания и переключение кодов, и массовых заимствований. Тогда как термин "переключения кодов» подчеркивает переход билингва от одной грамматической системы к другой, термин “смешивания кодов» предполагает наличие гибридных форм, связанные с обеими грамматиками. Иными словами, смешивания кодов подчеркивает формальные аспекты языковых структур или лингвистической компетенции, тогда как переключение кодов подчеркивает речевую активность (linguistic performance).

Психолингвистическое направления по изучению переключения речевых кодов в билингвальной среде объясняет какие аспекты языковой компетенции билингвов позволяют им менять коды. Чаще всего выбор иноязычной формы предусматривает отказ от имеющегося в системе языка преемника синонимической формы, тем самым ему противопоставляется альтернативный способ выражения коммуникативных интенций на иностранном языке.

Цель нашей научной статьи состоит в том, что бы представить функционирование смешивания и переключения кодов на материалах мемуарных («Плянета Ди-Пи») и эпистолярных произведений украинских писателей-эмигрантов в Канаде, в частности Уласа Алексеевича Самчука с его коллегами по перу, издателями и др. В качестве основных методов исследования были использованы: метод сравнительного анализа, позволяющего выявить англоязычные вкрапления как единицы английского языка, детерминирующих национально-культурную специфику английского языка; метод компонентного анализа, который позволил выявить семантические взаимосвязи английских реалий; дескриптивный метод и метод контент-анализа.

Объектом исследования являются речевые коды украинской эмиграции (мемуарные и эпистолярные произведения Уласа Самчука).

Предмет анализа - особенности смешивания и переключения речевых кодов украинской эмиграции Канады (в частности мемуарные и эпистолярные произведения Уласа Самчука). 
Змішування та перемикання мовленнєвих кодів української еміграції...

В ходе исследования мы пришли к выводу, что адресат и адресанты, настоящие мастера художественного слова, почти не допускают в речи на украинском языке английских вкраплений, или же такие вкрапления используются намеренно и являются средством языковой игры.

Ключевые слова: переключение языкового кода, смешивание речевых кодов, языковой контакт, эпистола, мемуаристика. 